Check for updates

Cite this: RSC Adv., 2019, 9, 4621

Received 15th November 2018

Accepted 29th January 2019

DOI: $10.1039 / \mathrm{c} 8 \mathrm{ra0} 0421 \mathrm{~g}$

rsc.li/rsc-advances

\section{Quantification of azide groups on a material surface and a biomolecule using a clickable and cleavable fluorescent compound $\dagger$}

\author{
Rika Sakai, Hiroki Iguchi and Tatsuo Maruyama (iD *
}

Here, we propose a novel method for quantifying azide groups on a solid surface and a protein using a clickable and cleavable fluorescent compound. The clickable and cleavable fluorescent compound conjugates with the azide groups on the material surface and the fluorophore is then liberated into the solvent via a cleavage reaction, which can be simply quantified with a conventional fluorometer.

\section{Introduction}

A bioorthogonal reaction is a chemical reaction that can be selectively and reliably performed in a complex biological environment without non-favorable interactions and interference with the biological system. ${ }^{1-3}$ Huisgen 1,3-dipolar cycloaddition between an azide and an alkyne (the azide/alkyne cycloaddition click reaction), which is one of the most famous bioorthogonal reactions, proceeds in a high yield under mild aqueous conditions without byproducts. ${ }^{4-6}$ This chemistry has been applied to a number of biomolecules and synthetic compounds to create multifunction-integrated molecular systems. This click reaction has also been used to immobilize biomolecules, ligands, and polymers on substrate surfaces ${ }^{7-11}$ for microarray preparation, ${ }^{12}$ fabrication of biomolecule-conjugated nanoparticles ${ }^{13-16}$ and fluorescent labeling of living cells. ${ }^{17-19}$

When click chemistry is applied to sensitive analytical and biological devices, quantification of the reactive sites plays an important role in controlling the amount of azide groups (or alkyne groups) present on a substrate surface, because the surface density of the functional molecules affects the performance of the substrate. ${ }^{20,21}$ However, to our knowledge, there have been no reports of quantification methods for clickable moieties (azide and alkyne groups) on substrate surfaces. Conventional surface analysis methods, such as X-ray photon spectroscopy (XPS), Fourier transform infrared spectroscopy and secondary-ion mass spectrometry are qualitative and provide information about the elements or functional groups not only on the outermost surface but also those at a certain depth (e.g., $10 \mathrm{~nm}$ for XPS) from the surface..$^{22,23}$ These methods require a high vacuum environment or dry atmosphere, and the

Department of Chemical Science and Engineering, Graduate School of Engineering, Kobe University, 1-1 Rokkodai, Nada-ku, Kobe 657-8501, Japan.E-mail: tmarutcm@ crystal.kobe-u.ac.jp

$\dagger$ Electronic supplementary information (ESI) available: The experimental procedures, and additional results. See DOI: 10.1039/c8ra09421g surfaces of polymeric materials vary depending on the environment. Therefore, it is of great importance to quantify the clickable moieties on the outermost surface in a practical environment (e.g., aqueous solution) for surface modification based on click chemistry.

In this study, we aimed to develop a method for quantification of the azide groups present on the outermost surface in an aqueous environment. We synthesized a clickable and cleavable fluorescent compound that conjugates with the azide groups on the substrate surface via Huisgen 1,3-dipolar cycloaddition (Fig. 1). Hydrolysis of the ester bond in the fluorescent compound liberates the fluorophore into the bulk solution, which allows the azide groups on a substrate surface to be quantified with a conventional fluorometer. The present methodology can be also applied to the quantification of azide groups conjugated with a protein.

\section{Experimental}

\section{Materials}

2,4-Dihydroxybenzaldehyde, 2,2-dimethyl-1,3-dioxane-4,6-dione, piperidinium acetate, 2-hydroxy-4-methoxybenzaldehyde, propargyl- $\mathrm{PEG}_{4}$-alcohol, and azidobenzoic acid were purchased from Tokyo Chemical Industry (Tokyo, Japan). $\mathrm{K}_{2} \mathrm{CO}_{3}$, propargyl-

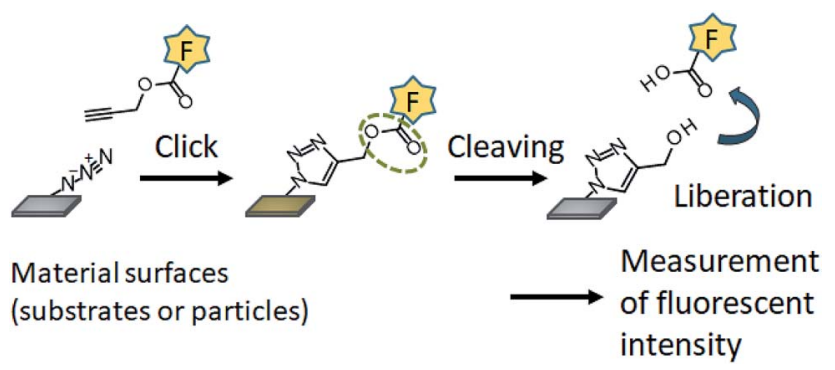

Fig. 1 Schematic of quantification of the azide groups on substrate surfaces using the clickable and cleavable fluorescent compound. 
bromide, $\mathrm{CuSO}_{4}, \beta$-casein from bovine milk, rhodamine $\mathrm{B}$ isothiocyanate (RITC), and Tris-EDTA buffer solution ( $\mathrm{pH} \mathrm{7)}$ were purchased from Sigma-Aldrich (St. Louis, MO). DBCO-s-s-amine was purchased from Conju-Probe LLC (San Diego, CA). The other chemicals were purchased from Wako Pure Chemical Industries, Ltd. (Osaka, Japan). $\mathrm{NH}_{2}$-PEG-resin particles $(10 \mu \mathrm{m})$ were purchased from Watanabe Chemical Industries (Hiroshima, Japan). Slide-A-Lyzer G2 dialysis cassettes (20k MWCO, $15 \mathrm{~mL}$ ) and micro BCA protein assay were purchased from Thermo Fisher Scientific (Waltham, USA). High-quality deionized (DI) water $(>15 \mathrm{M} \Omega \mathrm{cm}$ ) produced by an Elix-5 system (Millipore, Molsheim, France) was used in the experiments.

Synthesis of 7-methoxycoumarin-3-carboxylic acid. 2Hydroxy-4-methoxybenzaldehyde (50 mmol), 2,2-dimethyl-1,3dioxane-4,6-dione (50 $\mathrm{mmol})$, and piperidinium acetate (1 mmol) were dissolved in dehydrated ethanol $(25 \mathrm{~mL})$. The mixture was stirred at room temperature for $10 \mathrm{~min}$ and refluxed for $3 \mathrm{~h}$. The reaction mixture was cooled to room temperature, and then further cooled in an ice bath for $30 \mathrm{~min}$. The precipitate was collected by filtration and washed with ethanol three times. The product was dried overnight in a vacuum chamber.

${ }^{1} \mathrm{H}-\mathrm{NMR}\left(500 \mathrm{MHz}, \mathrm{CDCl}_{3}\right): \delta(\mathrm{ppm}) 3.97(\mathrm{~s}, 3 \mathrm{H}), 6.93(\mathrm{~d}, 1 \mathrm{H}, J$ $=2.2 \mathrm{~Hz}), 7.03(\mathrm{dd}, 1 \mathrm{H}, J=2.6,8.9 \mathrm{~Hz}), 7.65(\mathrm{~d}, 1 \mathrm{H}, J=8.8 \mathrm{~Hz})$, $8.86(\mathrm{~s}, 1 \mathrm{H}), 12.18(\mathrm{~s}, 1 \mathrm{H})$. DART-TOF/MS $(\mathrm{m} / \mathrm{z}):[\mathrm{M}+\mathrm{H}]^{+}$calcd for $\mathrm{C}_{11} \mathrm{H}_{9} \mathrm{O}_{5}$, 221.0; found, 221.0. Yield: $83 \%$.

Synthesis of $\mathbf{C} \equiv \mathbf{C}-\mathbf{C M R N}$. Propargyl bromide $(0.4 \mathrm{mmol})$ was added to a dehydrated DMF solution $(7 \mathrm{~mL})$ containing 7-methoxycoumarin-3-carboxylic acid $(0.2 \mathrm{mmol})$ and $\mathrm{K}_{2} \mathrm{CO}_{3}$ $(0.6 \mathrm{mmol})$. The solution was stirred at room temperature for $24 \mathrm{~h}$. Crude $\mathrm{C} \equiv \mathrm{C}-\mathrm{CMRN}$ was obtained as a yellow powder after filtration and evaporation. A HPLC system (LC-20AT, Shimadzu, Kyoto, Japan) equipped with an Inertsil ODS-3 column $(10 \mathrm{~mm}$ $\times 250 \mathrm{~mm}$, GL Science, Tokyo, Japan) was used to purify $\mathrm{C} \equiv \mathrm{C}-$ CMRN. The mobile phase was water containing $0.1 \mathrm{wt} \%$ trifluoroacetic acid (TFA) and acetonitrile containing $0.1 \mathrm{wt} \%$ TFA

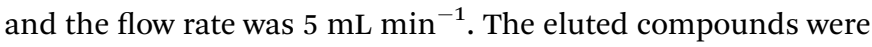
observed by measuring the absorbance at $350 \mathrm{~nm}$. The gradient started at $30 \%$ acetonitrile and $70 \%$ water, and the proportion of acetonitrile increased to $100 \%$ over $30 \mathrm{~min}$. Isocratic $100 \%$ acetonitrile was maintained for $10 \mathrm{~min}$.

${ }^{1} \mathrm{H}-\mathrm{NMR}\left(500 \mathrm{MHz}, \mathrm{CDCl}_{3}\right): \delta(\mathrm{ppm}) 3.91(\mathrm{~s}, 3 \mathrm{H}), 4.93(\mathrm{~s}, 2 \mathrm{H})$, $6.83(\mathrm{~s}, 1 \mathrm{H}), 6.91(\mathrm{dd}, 1 \mathrm{H}, J=2.5,8.8 \mathrm{~Hz}), 7.52(\mathrm{~d}, 1 \mathrm{H}, J=8.8$ $\mathrm{Hz}), 8.58(\mathrm{~s}, 1 \mathrm{H})$, DART-TOF/MS $(\mathrm{m} / \mathrm{z}):[\mathrm{M}+\mathrm{H}]^{+}$calcd for $\mathrm{C}_{14} \mathrm{H}_{11} \mathrm{O}_{5}$, 259.1; found, 259.1. Yield: $12 \%$.

Click reaction of $\mathbf{C} \equiv \mathbf{C}-\mathbf{C M R N}$. A DMSO solution $(0.4 \mathrm{~mL})$ containing $4 \mathrm{mmol} \mathrm{C} \equiv \mathrm{C}-\mathrm{CMRN}$ and $4 \mathrm{mmol}$ azidobenzoic acid was mixed and stirred with an aqueous solution $(1 \mathrm{~mL})$ of $0.4 \mathrm{mmol} \mathrm{CuSO}_{4}$ and $2 \mathrm{mmol}$ sodium ascorbate at $25{ }^{\circ} \mathrm{C}$ in a water bath for $3 \mathrm{~h}$. This solution was evaporated and analyzed by HPLC (Fig. S1 $\dagger$ ). The HPLC fractions of the reaction products were collected and lyophilized.

${ }^{1} \mathrm{H}-\mathrm{NMR}\left(500 \mathrm{MHz}, \mathrm{DMSO}-\mathrm{d}_{6}\right): \delta(\mathrm{ppm}) 3.96(\mathrm{~s}, 3 \mathrm{H}), 5.57(\mathrm{~s}$, $2 \mathrm{H}), 6.83(\mathrm{~s}, 1 \mathrm{H}), 6.91(\mathrm{dd}, 1 \mathrm{H}, J=2.5,8.8 \mathrm{~Hz}), 7.52(\mathrm{~d}, 1 \mathrm{H}, J=$ $8.5 \mathrm{~Hz}), 7.90(\mathrm{~d}, 2 \mathrm{H}, J=8.8 \mathrm{~Hz}), 8.25$ (d, 2H, $=9.2 \mathrm{~Hz}), 8.09$ (d, $2 \mathrm{H}, J=8.9 \mathrm{~Hz}), 8.69(\mathrm{~s}, 1 \mathrm{H}), 8.86(\mathrm{~s}, 1 \mathrm{H})$.
Synthesis of $\mathbf{C} \equiv \mathbf{C}-\mathbf{E G}_{\mathbf{3}}-\mathbf{C M R N}$. Propargyl-PEG ${ }_{4}$-alcohol $(0.2$ $\mathrm{mmol}$ ) was added to a solution of 7-methoxycoumarin-3carboxylic acid (0.4 mmol), 1-ethyl-3-(3-dimethylaminopropyl) carbodiimide, hydrochloride (WSC, $0.24 \mathrm{mmol}$ ) and $N, N$ dimethyl-4-aminopyridine (DMAP, $0.2 \mathrm{mmol}$ ) in DMF (1 mL). The solution was stirred at room temperature for $3 \mathrm{~h}$. The product was purified by HPLC. After evaporation and freezedrying, the product was obtained as a yellow powder.

${ }^{1} \mathrm{H}-\mathrm{NMR}\left(500 \mathrm{MHz}, \mathrm{CDCl}_{3}\right): \delta(\mathrm{ppm}) 2.41(\mathrm{t}, 1 \mathrm{H}), 3.70-3.73$ $(\mathrm{m}, 8 \mathrm{H}), 3.84(\mathrm{t}, 2 \mathrm{H}), 3.91(\mathrm{~s}, 3 \mathrm{H}), 4.19(\mathrm{~d}, 2 \mathrm{H}, J=2.2 \mathrm{~Hz}), 7.88(\mathrm{t}$, $2 \mathrm{H}, J=9 \mathrm{~Hz}), 6.82(\mathrm{~s}, 1 \mathrm{H}), 6.90(\mathrm{dd}, 2 \mathrm{H}, J=2.5,8.5 \mathrm{~Hz}), 7.51(\mathrm{~d}$, $1 \mathrm{H}, J=8.9 \mathrm{~Hz}), 8.53(\mathrm{~s}, 1 \mathrm{H})$. DART-TOF/MS $(\mathrm{m} / \mathrm{z}):[\mathrm{M}+\mathrm{H}]^{+}$calcd for $\mathrm{C}_{20} \mathrm{H}_{23} \mathrm{O}_{8}, 391.1$; found, 391.2. Yield: $21 \%$.

Click reaction of $\mathbf{C} \equiv \mathbf{C}-\mathbf{E G}_{3}-\mathbf{C M R N}$. A solution of $\mathrm{C} \equiv \mathrm{C}-\mathrm{EG}_{3}-$ CMRN $(2.5 \mu \mathrm{mol})$ and azidobenzoic acid $(2.5 \mu \mathrm{mol})$ in DMSO $(0.4 \mathrm{~mL})$ was mixed and stirred with an aqueous solution (1.6 $\mathrm{mL})$ of $\mathrm{CuSO}_{4}(6 \mu \mathrm{mol})$ and sodium ascorbate $(30 \mu \mathrm{mol})$ at $37^{\circ} \mathrm{C}$ for $3 \mathrm{~h}$. The solution was analyzed as described above (click reaction of $\left.\mathrm{C} \equiv \mathrm{C}-\mathrm{EG}_{3}-\mathrm{CMRN}\right)$.

${ }^{1} \mathrm{H}-\mathrm{NMR}$ (500 MHz, DMSO-d ${ }_{6}$ ): $\delta$ (ppm) 3.54-3.61 (m, 8H), $3.71(\mathrm{t}, 2 \mathrm{H}), 3.88(\mathrm{~s}, 3 \mathrm{H}), 4.34(\mathrm{t}, 2 \mathrm{H}, J=2.2 \mathrm{~Hz}), 4.61(\mathrm{~s}, 2 \mathrm{H}), 6.98$ $(\mathrm{dd}, 1 \mathrm{H}, J=2.5,8.8 \mathrm{~Hz}), 7.01(\mathrm{~s}, 1 \mathrm{H}), 7.82(\mathrm{~d}, 1 \mathrm{H}, J=8.6 \mathrm{~Hz}), 7.98$ $(\mathrm{d}, 2 \mathrm{H}, J=8.5 \mathrm{~Hz}), 8.09$ (d, $2 \mathrm{H}, J=8.9 \mathrm{~Hz}), 8.69(\mathrm{~s}, 1 \mathrm{H}), 8.86$ (s, 1H). Yield: $96 \%$.

Cleavage. $\mathrm{NaOH}$ solution $(0.1 \mathrm{M}, 0.5 \mathrm{~mL})$ was added to the solution after the click reaction of $\mathrm{C} \equiv \mathrm{C}-\mathrm{EG}_{3}-\mathrm{CMRN}$ with azidobenzoic acid. The mixture was stirred at $37{ }^{\circ} \mathrm{C}$ for $3 \mathrm{~h}$ and analyzed by HPLC.

Azidation of the resin particles. The resin particles had $65 \mathrm{mmol} \mathrm{g}^{-1}$ amino groups on their surfaces. A dispersion of amino-resin particles (3.8 $\mu \mathrm{mol}$ amino groups), azidobenzoic acid (380 $\mu \mathrm{mol})$, and 4-(4,6-dimethoxy-1,3,5-triazin-2-yl)-4methylmorpholinium chloride (DMT-MM, $75 \mu \mathrm{mol}$ ) was mixed in DMSO (3 mL) and stirred at $37^{\circ} \mathrm{C}$ for $24 \mathrm{~h}$ to conjugate azidobenzoic acid with the amino groups on the resin particles. The resin particles were washed four times with methanol (6 $\mathrm{mL})$ and water $(6 \mathrm{~mL})$.

Quantification of the azide groups on the resin particles using $\mathbf{C} \equiv \mathbf{C}-\mathbf{C M R N}$. Azidated resin particles (0, 0.1875, 0.375, or 0.75 $\mathrm{mg})$ were dispersed in water $(1.8 \mathrm{~mL})$ containing $\mathrm{CuSO}_{4}(1 \mu \mathrm{mol})$ and sodium ascorbate $(4 \mu \mathrm{mol})$. The dispersion was added to $1 \mathrm{mM} \mathrm{C} \equiv \mathrm{C}-\mathrm{EG}_{3}-\mathrm{CMRN}$ in DMSO $(0.1 \mathrm{~mL})$ and shaken at $40{ }^{\circ} \mathrm{C}$ for $24 \mathrm{~h}$. After centrifugation, the supernatant was removed and the resin particles were washed three times with methanol and water. The resin particles were dispersed in $\mathrm{NaOH}$ aqueous solution ( $1 \mathrm{M}, 0.2 \mathrm{~mL}$ ) and then shaken at $37^{\circ} \mathrm{C}$ for $24 \mathrm{~h}$ to liberate CMRN from the resin particles. After centrifugation, $\mathrm{HCl}$ solution $(1 \mathrm{M}, 0.2 \mathrm{~mL})$ and phosphate buffer $(0.1 \mathrm{M}, \mathrm{pH} 7.4,2 \mathrm{~mL})$ were added to neutralize the supernatant. The fluorescence intensity of the neutralized solution was measured with a fluorescence spectrophotometer. The excitation and emission wavelengths were 335 and $406.5 \mathrm{~nm}$, respectively. The excitation and emission band widths were $5 \mathrm{~nm}$. The standard curve of a liberated fluorophore in phosphate buffer is shown in Fig. S2a. $\dagger$ Quantification was performed in triplicate, unless specified otherwise. 
Quantification of the azide groups on the resin particles using strain-promoted (Cu-free) click chemistry (Fig. S3 $\uparrow$ ). Azidated resin particles $(0.1875,0.375$, or $0.75 \mathrm{mg})$ were dispersed in $10 \mathrm{mM}$ $\mathrm{HCl}_{\mathrm{aq}}(1.4 \mathrm{~mL})$. The dispersion was added to $0.6 \mathrm{~mL}$ tetrahydrofuran (THF) containing $1 \mathrm{mM}$ DBCO-s-s- $\mathrm{NH}_{2}$ and shaken at $40{ }^{\circ} \mathrm{C}$ for $12 \mathrm{~h}$. After centrifugation, the supernatant was removed and the resin particles were washed three times with THF/10 $\mathrm{mM} \mathrm{HCl}$ aqueous solution $(1 / 1, v / v)$ and once with phosphate buffer (50 mM, pH 8). The resin particles dispersed in phosphate buffer (50 mM, $1 \mathrm{~mL}$ ) were added to phosphate buffer $(50 \mathrm{mM}, 2 \mathrm{~mL})$ containing $1 \mathrm{mM}$ RITC and $10 \mathrm{vol} \%$ trimethylamine (TEA) and then shaken at $40{ }^{\circ} \mathrm{C}$ for $3 \mathrm{~h}$. The supernatant was removed and phosphate buffer (50 mM, $2 \mathrm{~mL}$ ) containing $1 \mathrm{mM}$ RITC and 10 vol\% TEA was added again and shaken at $40{ }^{\circ} \mathrm{C}$ for $3 \mathrm{~h}$. After centrifugation, the supernatant was removed and the resin particles were washed with methanol/10 $\mathrm{mM} \mathrm{NaOH}$ aqueous solution $(1 / 1, v / v)$, methanol/10 mM $\mathrm{HCl}$ aqueous solution $(1 / 1, \mathrm{v} / \mathrm{v})$ and phosphate buffer (50 mM, pH 8). After centrifugation, phosphate buffer (50 mM, pH 8, $2 \mathrm{~mL}$ ) containing $4 \mathrm{mM}$ tris(2-carboxyethyl) phosphine were added to liberate the fluorophore. The fluorescence intensity of the solution was measured with a fluorescence spectrophotometer. The excitation and emission wavelengths were 495 and $515 \mathrm{~nm}$, respectively. The excitation and emission band widths were $5 \mathrm{~nm}$.

Quantification of the azide groups on $\beta$-casein by TNBS. $\beta$ Casein was dissolved in $0.1 \mathrm{M} \mathrm{NaHCO}$ buffer $(\mathrm{pH}$ 8) at concentrations of $20-200 \mu \mathrm{g} \mathrm{mL} \mathrm{mL}^{-1}$ to construct the standard curve. A solution of $0.01 \%(\mathrm{w} / \mathrm{v})$ TNBS $(0.25 \mathrm{~mL})$ was added to sample solutions $(0.5 \mathrm{~mL})$ containing $100 \mu \mathrm{g} \mathrm{mL} \mathrm{m}^{-1}$ azidated $\beta$ casein or $\beta$-casein, and the solutions were then incubated at $37{ }^{\circ} \mathrm{C}$ for $2 \mathrm{~h}$. After the reaction, $10 \%$ SDS aqueous solution (0.25 $\mathrm{mL}$ ) and $1 \mathrm{M} \mathrm{HCl}$ aqueous solution $(0.125 \mathrm{~mL})$ were added to the sample solution to quench the TNBS reaction. The absorbance of the solutions was measured at $335 \mathrm{~nm}$.

Quantification of the azide groups on azidated $\beta$-casein. Azidated casein (50 nmol) was dissolved in $25 \mathrm{mM} \mathrm{NaHCO}_{3}$ buffer ( $\mathrm{pH}$ 8, $1.2 \mathrm{~mL})$ containing $\mathrm{CuSO}_{4}(2.4 \mu \mathrm{mol})$ and sodium ascorbate $(12 \mu \mathrm{mol}) . \mathrm{C} \equiv \mathrm{C}-\mathrm{EG}_{3}-\mathrm{CMRN}(5 \mu \mathrm{mol})$ in DMSO (0.4 $\mathrm{mL}$ ) was added to the solution and the solution was stirred at $37{ }^{\circ} \mathrm{C}$ for $3 \mathrm{~h}$. After the reaction, excess $\mathrm{C} \equiv \mathrm{C}-\mathrm{EG}_{3}-\mathrm{CMRN}$ and $\mathrm{Cu}(\mathrm{I})$ catalyst were removed by dialysis for 2 days. $\mathrm{NaOH}$ solution $(1 \mathrm{M}, 0.5 \mathrm{~mL})$ was added to the solution $(0.5 \mathrm{~mL})$ and the solution was then shaken at $40{ }^{\circ} \mathrm{C}$ for $2 \mathrm{~h}$ to liberate CMRN fluorophore from $\beta$-casein. $\mathrm{HCl}$ solution $(1 \mathrm{M}, 0.5 \mathrm{~mL})$ and $\mathrm{NaHCO}_{3}$ buffer $(1 \mathrm{M}, \mathrm{pH} 8,2 \mathrm{~mL}$ ) were added to neutralize the solution. The fluorescent intensity of the solution was measured with a fluorescent spectrometer. The excitation and emission bands were 335 and $406.5 \mathrm{~nm}$, respectively. The standard curve of a liberated fluorophore in carbonate buffer is shown in Fig. S2b. $\dagger$ Quantification was performed in triplicate, unless specified otherwise.

\section{Results and discussion}

First, we designed and synthesized two different types of clickable and cleavable fluorescent compounds: $\mathrm{C} \equiv \mathrm{C}-\mathrm{CMRN}$ and $\mathrm{C} \equiv \mathrm{C}-\mathrm{EG}_{3}-\mathrm{CMRN}$ (Fig. 2a). The alkyne group acts as the

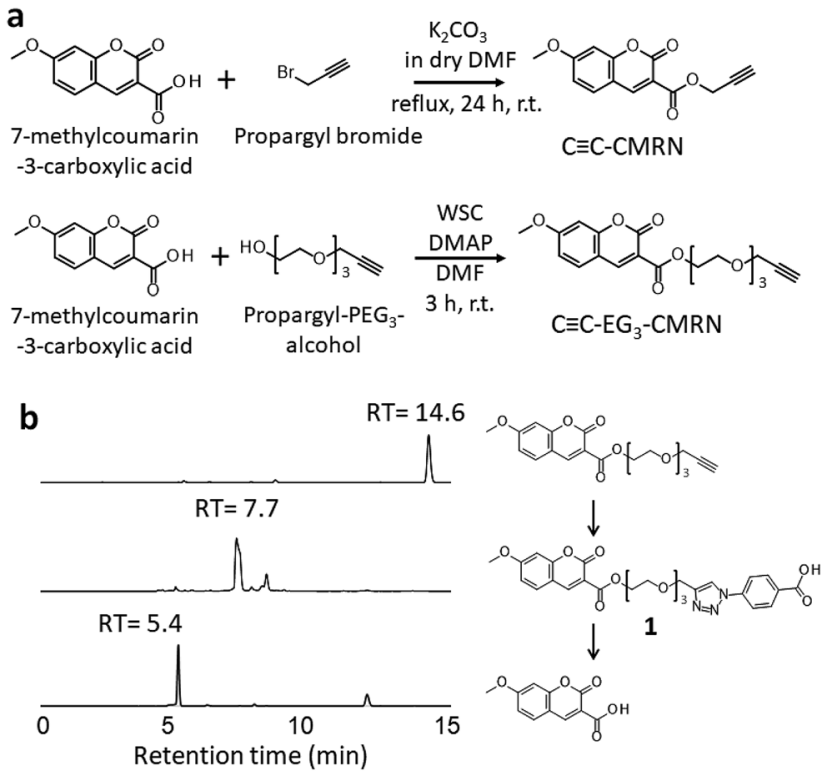

Fig. 2 (a) Synthesis of the clickable and cleavable fluorescent compounds $\mathrm{C} \equiv \mathrm{C}-\mathrm{CMRN}$ and $\mathrm{C} \equiv \mathrm{C}-\mathrm{EG}_{3}-\mathrm{CMRN}$. (b) HPLC profiles of $\mathrm{C} \equiv \mathrm{C}-\mathrm{EG}_{3}-\mathrm{CMRN}$ after the click reaction and after subsequent hydrolysis.

clickable part and the ester bond acts as the cleavable part in hydrolysis. $\mathrm{C} \equiv \mathrm{C}-\mathrm{CMRN}$ has no spacer between the ester bond and alkyne, but $\mathrm{C} \equiv \mathrm{C}-\mathrm{EG}_{3}-\mathrm{CMRN}$ has an oligo (ethylene glycol) spacer. The click reactivities of $\mathrm{C} \equiv \mathrm{C}-\mathrm{CMRN}$ and $\mathrm{C} \equiv \mathrm{C}-\mathrm{EG}_{3}-$ CMRN were investigated in a homogeneous solution. Azidobenzoic acid was used as a model azide compound and the click reaction was performed with a copper catalyst in a mixture of water/dimethylformamide (DMF) (5/1, v/v). High-performance liquid chromatography (HPLC) measurements of $\mathrm{C} \equiv \mathrm{C}-\mathrm{CMRN}$ indicate simultaneous synthesis of compound $1^{\prime}$ (at a retention time (RT) of $15.3 \mathrm{~min}$ ) and production of 7-methylcoumarin-3carboxylic acid (Fig. S1 $\dagger$ ), indicating that hydrolysis of the ester bond is probably due to chelation of a $\mathrm{Cu}$ ion at the neighboring site. HPLC measurements of $\mathrm{C} \equiv \mathrm{C}-\mathrm{EG}_{3}-\mathrm{CMRN}$ reveal that the peak at $\mathrm{RT}=14.6 \mathrm{~min}$ disappears and a peak at $\mathrm{RT}=7.7 \mathrm{~min}$ appears (Fig. 2b). ${ }^{1} \mathrm{H}$-NMR analysis of these fractions reveals that the peaks at $\mathrm{RT}=14.6$ and $7.7 \mathrm{~min}$ correspond to $\mathrm{C} \equiv \mathrm{C}-\mathrm{EG}_{3}-\mathrm{CMRN}$ and compound 1 (the product of the click reaction), respectively. These results indicate that $\mathrm{C} \equiv \mathrm{C}-\mathrm{EG}_{3}-\mathrm{CMRN}$ can be used as a substrate in the azide/alkyne click reaction and that the reaction proceeds in high yield $(>96 \%)$.

Next, we investigated hydrolysis of the ester bond of $\mathrm{C} \equiv \mathrm{C}-$ $\mathrm{EG}_{3}-\mathrm{CMRN}$. $\mathrm{NaOH}$ aqueous solution was added to the solution containing compound 1 to give a final $\mathrm{NaOH}$ concentration of $0.1 \mathrm{M}$, and the mixture was then stirred at $37^{\circ} \mathrm{C}$ for $3 \mathrm{~h}$. HPLC measurements show that the peak of compound 1 (at RT $=7.7$ min) completely disappears and a new peak of 7-methylcoumarin-3-carboxylic acid appears at RT $=5.4 \mathrm{~min}$ (Fig. 2b). These results demonstrate that compound 1, which is the product of the $\mathrm{C} \equiv \mathrm{C}-\mathrm{EG}_{3}-\mathrm{CMRN} /$ azidobenzoic acid click reaction, can be hydrolyzed by aqueous $\mathrm{NaOH}$ to liberate its fluorophore. 
We then attempted to quantify the azide groups on resin particles using $\mathrm{C} \equiv \mathrm{C}_{-}-\mathrm{EG}_{3}-\mathrm{CMRN}$. In a previous study, we reported that the resin particles have $65 \mathrm{nmol} \mathrm{mg}^{-1}$ amino groups. ${ }^{24}$ Before quantification, we produced azide groups on the resin particles by the condensation reaction between azidobenzoic acid and the amino groups on the resin particles (azidation, Fig. 3a). The azide groups on the resin particle surfaces were quantified using $\mathrm{C} \equiv \mathrm{C}_{-} \mathrm{EG}_{3}-\mathrm{CMRN}$. Azidated resin particles $(0,0.19,0.38$, or $0.75 \mathrm{mg})$ were dispersed in water $(1.8 \mathrm{~mL})$ containing $\mathrm{CuSO}_{4}(1 \mu \mathrm{mol})$ and sodium ascorbate $(4 \mu \mathrm{mol})$. The dispersion was mixed with dimethyl sulfoxide (DMSO, $0.1 \mathrm{~mL}$ ) containing $1 \mathrm{mM} \mathrm{C} \equiv \mathrm{C}_{-}-\mathrm{EG}_{3}-\mathrm{CMRN}$ and shaken at room temperature for $24 \mathrm{~h}$. After washing the resin particles, the resin particles were dispersed in $\mathrm{NaOH}$ aqueous solution (final concentration of $0.1 \mathrm{M}$ ) to liberate the CMRN fluorophore from the resin particles. After centrifugation and neutralization, the fluorescence intensity of the solution was measured with a conventional fluorescence spectrophotometer. There is high linearity between the amount of particles and the fluorescence intensity of the liberated fluorophore (Fig. 2b). The quantified value of the azide groups on the resin particles is $55 \mathrm{nmol} \mathrm{mg}^{-1}$, which is comparable with the amount of amino groups on the resin particles. The slightly smaller value for the azide groups is because of the yield of azidation of the amino groups on the resin particles. These results suggest successful quantification of the azide groups on the resin particles using the proposed method. The standard curve (Fig. S4†) shows that the limit of detection of the present method was $5 \mathrm{nmol} \mathrm{ml}^{-1}$, which means that azide groups of 5 pmol on a surface was detected when using $1 \mathrm{~mL}$ aqueous solution of liberated fluorophore.

While the above investigations employed $\mathrm{Cu}(\mathrm{I})$ as a catalyst for 1,3-dipolar cycloaddition of azide and alkyne, a $\mathrm{Cu}$-free click reaction (strain-promoted azide-alkyne cycloaddition) using a cycloalkyne has attracted a broad range of attention because of no use of a catalyst. ${ }^{25}$ We then attempted to quantify the azide groups on resin surfaces using a $\mathrm{Cu}$-free click reaction (Fig. S3†). Although a dibenzocyclooctyne (DBCO) derivative is a useful functional molecule for a $\mathrm{Cu}$-free click reaction, its water

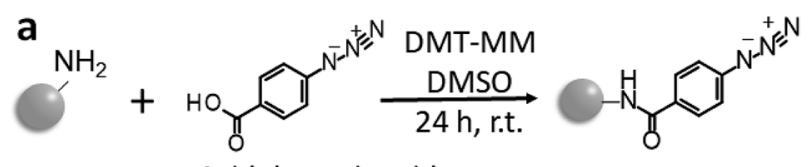

Resin particle Azidobenzoic acid

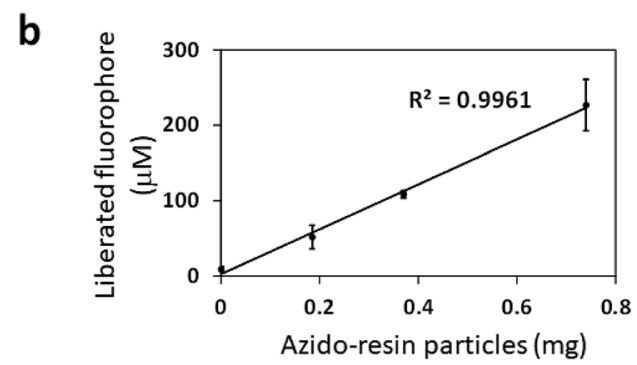

Fig. 3 (a) Schematic of azidation of the amino groups on the resin particles. (b) Quantification of the azide groups on the resin particles using $\mathrm{C} \equiv \mathrm{C}-\mathrm{EG}_{3}-\mathrm{CMRN}$. solubility is very low. We conjugated DBCO-s-s-amine with azide groups on resin surfaces and then the resultant amino groups were conjugated with rhodamine B isothiocyanate (RITC). The disulfide bond was cleaved by a reducing agent (TCEP) to liberate the fluorophore, which was measured using a fluorometer. Although the liberated fluorophore increased linearly with the amount of azidated resin particles (Fig. S5†), we detected only 4.2 nmol azide groups per $1 \mathrm{mg}$ resin. The remarkably low amount of azide groups quantified might be explained by the following possible reasons. (i) The sterically bulky structure of DBCO-s-samine affected its conjugation with an azide group on a surface, leading to a low conjugation ratio. (ii) A mixture of $\mathrm{THF} /$ water, which was used to dissolve DBCO-s-s-amine for a $\mathrm{Cu}$ free click reaction, altered the surface composition of resin, resulting in the inhibition of the azide group quantification. These results suggest that a relatively small fluorescent compound, which has water solubility and avoids steric hindrance, is appropriate for the quantification of azide groups on a surface. The following experiments were carried out using $\mathrm{C} \equiv \mathrm{C}_{-}-\mathrm{EG}_{3}-\mathrm{CMRN}$.

In the last decade, clickable moieties have often been introduced to biomolecules (e.g., proteins and nucleic acids) to create functionally engineered biomolecules and immobilize them on various surfaces. ${ }^{26-30}$ Therefore, we then investigated quantification of azide groups introduced to a protein. $\beta$-Casein was chosen as a model protein and azide groups were introduced to the amino groups of $\beta$-casein by $N$-hydroxysuccinimide ester chemistry (Fig. 4a). $\beta$-Casein has 12 amino groups. ${ }^{31}$ The TNBS method $^{32,33}$ shows that the azidation procedure conjugates $86 \%$ of the amino groups with azidobenzoic acid. Azidated $\beta$-casein $(50 \mathrm{nmol})$ in an aqueous buffer $(\mathrm{pH} 7.0,1.2 \mathrm{~mL})$ containing $\mathrm{CuSO}_{4}(2.4 \mu \mathrm{mol})$ and sodium ascorbate $(12 \mu \mathrm{mol})$ was mixed with DMSO $(0.4 \mathrm{~mL})$ containing $\mathrm{C} \equiv \mathrm{C}_{-} \mathrm{EG}_{3}-\mathrm{CMRN}(5 \mu \mathrm{mol})$ and then shaken at $37{ }^{\circ} \mathrm{C}$ for $3 \mathrm{~h}$. After dialysis to remove excess $\mathrm{C} \equiv \mathrm{C}_{-} \mathrm{EG}_{3}-\mathrm{CMRN}$ and the $\mathrm{Cu}$ catalyst, $\mathrm{NaOH}$ aqueous solution was added to the solution to liberate the CMRN moiety from azidated $\beta$-casein.

Fluorescence measurement of the solution shows $410 \mathrm{nmol}$ CMRN moieties per milligram of casein (Fig. $4 \mathrm{~b}$ ), meaning that $81 \%$ of the amino groups of $\beta$-casein are azidated. The obtained azidation ratio is comparable with the result of the TNBS method.

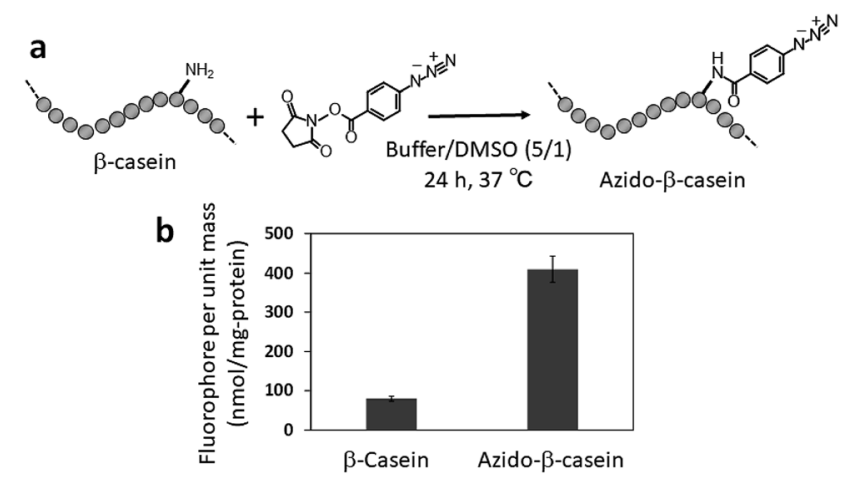

Fig. 4 (a) Schematic of azidation of the amino groups on $\beta$-casein. (b) Quantification of the azide groups on $\beta$-casein. 


\section{Conclusions}

In conclusion, we have proposed a novel approach to quantify the azide groups on a material surface and on a protein using a clickable and cleavable fluorescent compound $\left(\mathrm{C} \equiv \mathrm{C}-\mathrm{EG}_{3}-\right.$ CMRN). This is the first time that quantification of the azide groups on a solid material and a biomolecule has been achieved. Quantitative analysis of the clickable moieties on a surface will play an important role in surface chemistry and extend the applicability of the azide/alkyne cycloaddition click reaction on surfaces and at interfaces.

\section{Conflicts of interest}

There are no conflicts to declare.

\section{Acknowledgements}

We thank Prof. A. Mori for his technical help. This work was supported by Special Coordination Funds for Promoting Science and Technology, Creation of Innovation Centers for Advanced Interdisciplinary Research Areas (Innovative Bioproduction Kobe), MEXT, Japan and also by JSPS KAKENHI (16H04577, 18K18976 and 18H04556).

\section{Notes and references}

1 E. M. Sletten and C. R. Bertozzi, Acc. Chem. Res., 2011, 44, 666-676.

2 C. P. Ramil and Q. Lin, Chem. Commun., 2013, 49, 1100711022.

3 N. K. Devaraj, ACS Cent. Sci., 2018, 4, 952-959.

4 R. Huissgen, Angew. Chem., Int. Ed., 1963, 2, 565-632.

5 V. V. Rostovtsev, L. G. Green, V. V. Fokin and K. B. Sharpless, Angew. Chem., Int. Ed., 2002, 41, 2596-2599.

6 C. W. Tornoe, C. Christensen and M. Meldal, J. Org. Chem., 2002, 67, 3057-3064.

7 B. P. Duckworth, J. H. Xu, T. A. Taton, A. Guo and M. D. Distefano, Bioconjugate Chem., 2006, 17, 967-974.

$8 \mathrm{~W}$. H. Binder and R. Sachsenhofer, Macromol. Rapid Commun., 2008, 29, 952-981.

9 L. A. Canalle, S. S. van Berkel, L. T. de Haan and J. C. M. van Hest, Adv. Funct. Mater., 2009, 19, 3464-3470.

10 G. A. Hudalla and W. L. Murphy, Langmuir, 2009, 25, 57375746.

11 X. Deng, C. Friedmann and J. Lahann, Angew. Chem., Int. Ed., 2011, 50, 6522-6526.
12 X. L. Sun, C. L. Stabler, C. S. Cazalis and E. L. Chaikof, Bioconjugate Chem., 2006, 17, 52-57.

13 J. F. Lutz and Z. Zarafshani, Adv. Drug Delivery Rev., 2008, 60, 958-970.

14 K. Patel, S. Angelos, W. R. Dichtel, A. Coskun, Y. W. Yang, J. I. Zink and J. F. Stoddart, J. Am. Chem. Soc., 2008, 130, 2382-2383.

15 Y. Zhou, S. X. Wang, K. Zhang and X. Y. Jiang, Angew. Chem., Int. Ed., 2008, 47, 7454-7456.

16 W. R. Algar, D. E. Prasuhn, M. H. Stewart, T. L. Jennings, J. B. Blanco-Canosa, P. E. Dawson and I. L. Medintz, Bioconjugate Chem., 2011, 22, 825-858.

17 N. J. Agard, J. M. Baskin, J. A. Prescher, A. Lo and C. R. Bertozzi, ACS Chem. Biol., 2006, 1, 644-648.

18 S. T. Laughlin, J. M. Baskin, S. L. Amacher and C. R. Bertozzi, Science, 2008, 320, 664-667.

19 X. H. Ning, J. Guo, M. A. Wolfert and G. J. Boons, Angew. Chem., Int. Ed., 2008, 47, 2253-2255.

20 A. Shimomura, T. Nishino and T. Maruyama, Langmuir, 2013, 29, 932-938.

21 K. Nishimori, S. Kitahata, T. Nishino and T. Maruyama, Langmuir, 2018, 34, 6396-6404.

22 R. F. Roberts, D. L. Allara, C. A. Pryde, D. N. E. Buchanan and N. D. Hobbins, Surf. Interface Anal., 1980, 2, 5-10.

23 N. J. Harrick, Internal reflection spectroscopy, Interscience Publishers, New York, 1967.

24 S. Shiota, S. Yamamoto, A. Shimomura, A. Ojida, T. Nishino and T. Maruyama, Langmuir, 2015, 31, 8824-8829.

25 N. J. Agard, J. A. Prescher and C. R. Bertozzi, J. Am. Chem. Soc., 2004, 126, 15046-15047.

26 F. de Moliner, N. Kielland, R. Lavilla and M. Vendrell, Angew. Chem., Int. Ed., 2017, 56, 3758-3769.

27 C. D. Spicer, E. T. Pashuck and M. M. Stevens, Chem. Rev., 2018, 118, 7702-7743.

28 Y. Zou, L. Zhang, L. Yang, F. Zhu, M. M. Ding, F. Lin, Z. Wang and Y. W. Li, J. Controlled Release, 2018, 273, 160-179.

29 A. C. Braun, M. Gutmann, T. Luhmann and L. Meinel, J. Controlled Release, 2018, 273, 68-85.

30 O. Boutureira and G. J. L. Bernardes, Chem. Rev., 2015, 115, 2174-2195.

31 J. M. Girardet, J. L. Courthaudon, S. Campagna, V. Puyjalon, D. Lorient and G. Linden, Int. Dairy J., 1999, 9, 409-410.

32 M. L. Kakade and I. E. Liener, Anal. Biochem., 1969, 27, 273280.

33 P. Cayot and G. Tainturier, Anal. Biochem., 1997, 249, 184200. 